\title{
Whistleblowing and Tri Hita Karana to Prevent Village Fund Fraud in Bali
}

\author{
Komang Adi Kurniawan Saputra $^{1 *}$, I Ketut Puja Wirya Sanjaya ${ }^{2}$ \\ Warmadewa University, Jl. Terompong No.24, Sumerta Kelod, Kec. Denpasar Tim., Kota Denpasar, Bali 80239 \\ ${ }^{1}$ komangadikurniawan@gmail.com \\ 2 pujaws@gmail.com \\ *corresponding author
}

ARTICLE INFO

\section{Article history}

Received 5 September 2019

Revised 12 October 2020

Accepted 30 October 2020

Keywords

Whistleblowing

Tri Hita Karana

Village Funds

Fraud

\begin{abstract}
This study aims to examine the whistleblowing and Tri Hita Karana variables on fraud prevention in managing village funds. By employing survey method with a questionnaire, 88 villages that received village funds in the Province of Bali were taken as samples. Data was analysis by using ordinary least square model, namely multiple linear regression. The results of this study indicates that the tri hita karana culture significantly influences fraud prevention in managing village funds, while the whistleblowing variable does not show a significant effect on the prevention of fraud in village fund management. In village government and village fund management, mutual trust, mutual respect and not a mutual accusation are apparent. This means that the village government in Bali believes both in national law and indigenous law or norms in overcoming fraudulent perpetrators.
\end{abstract}

This is an open access article under CC-BY-SA License

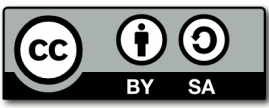

\section{Introduction}

Based on the Village Minister's Regulation, Development of Disadvantaged Regions, and Transmigration of the Republic of Indonesia Number 21 Year 2015 concerning Priority Determination of Village Fund Use in 2016, Village Funds are funds sourced from the state revenue and expenditure budget intended for villages that are transferred through the regional revenue and expenditure budget to fund the administration, community development, and empowerment. The government disbursed village funds from the central government to the Provincial and Regency/City levels in the amount of a total of Rp20.76 billion in 2016. With such large amount, competent management and close supervision for each village government is imperative. This is needed to avoid fraud that has been feared by the government and society.

Fraud is translated as deviation, as well as errors and irregularities each translated as errors and irregularities [1]. Fraud usually occurs if the existing control system is very weak and lacks supervision in financial management, with an element of intent in doing it. On the other hand, SAS No. 99 defines cheating as an intentional act to produce material misstatements in financial statements. The difference between irregularities and errors is what is the underlying action, i.e. whether the action is intentional or not [2]. Fraud is carried out to obtain profits in the form of money and wealth [3], or to avoid payment or loss of services, or avoid taxes and secure personal or business interests.

Several cases of fraud have been discovered by the Corruption Eradication Commission (KPK) in managing village funds. Weak regulatory aspects are considered contributing factors. 
Further, the authority overlap between the Ministry of Development of Disadvantaged Villages and the Ministry of Home Affairs often gives way for fraud.

To make it worse, related to governance, there is no standardization for the reference of village officials to design the Village Revenue and Expenditure Budget. The accountability report is considered prone to falsification. There were alleged projects played by the mafia who infiltrate villages and on behalf of villagers. This may occur because the work of the Regional Inspectorate has not been effective. For KPK and other related institutions such as the Ministry of Home Affairs, Ministry of PDT, and the Financial and Development Supervisory Agency, they are formulating an action plan to address this. The expected results will be in the form of a solution and an action plan in accordance with the authority of each agency, as well as the Regional Government in this case the Regional Inspectorate and institutions concerned with village funds. A strong commitment between institutions and personnel will create institutional integration that is not easily infiltrated by fraud, one of which is the culture of whistleblowing, which can be a way out to close existing fraud gaps. Whistleblowing is an effort to achieve an economic and social goal so that the perpetrators expect support from various parties so that this goal is achieved [4]. Whistleblowing is the disclosure of violations or disclosure of actions that are against the law, unethical/immoral actions or other actions that can harm the organization or stakeholders that are carried out by employees or leaders of the organization to the leadership of other organizations or institutions $[5,6]$.

The awareness of the community to conduct whistleblowing is also very useful in revealing corruption and fraud. A person who notifies the public or officials in charge of alleged dishonesty, illegal activities or mistakes that occur in government, public organizations, or the private sector is called a whistleblower [7]. Given that the whistleblowing system is sufficient enough to detect fraud, at present most government agencies such as the central government to village governments have complaints handling systems to reduce the phenomenon of corruption in public institutions [8].

Whistleblowing can be done internally and externally [4]. From the two sources of internal and external reporting, several benefits can be obtained if the whistleblowing is done internally. Problems within the organization can still be resolved internally before the full scandal is revealed outside. In addition, internal disclosures will create an ethical atmosphere in organizations where employees are encouraged to report unethical behavior. The internal settlement strongly supports the use of various approaches, including organizational culture inherent in each village. This is the basis for the use of local Balinese culture Tri Hita Karana (THK) as a research variable, because these cultural values have taken root in each of the Balinese Hindu communities. This research was conducted in the Province of Bali, precisely in nine regencies/cities because Bali consists of 716 villages.

The concept of THK is the concept of harmonization of relationships that are always guarded by the Balinese Hindu community including parahyangan (human relations with God), pawongan (human relations), and palemahan (human and environmental relations) sourced from the Bhagavad Gita $[9,10]$. Therefore, the THK concept that developed in Bali is a cultural concept rooted in religious teachings [11]. In the holy Vedic literature it is also found that the work ethic values of Hindus include: creativity, hard work without knowing despair, respecting time, harmonious cooperation, Satya wacana, ethical efficiency and full of initiative. The philosophy of Balinese culture of Tri Hita Karana emphasizes the balance theory, states that Hindu societies tend to view themselves and their environment as a system controlled by equilibrium values, and manifested in the following forms of behavior: (1) always want to adapt themselves to their environment. Bali maintains a strong pattern but is easy to accept adaptation, (2) always wants to create peace within itself and balance with its environment [12].

Prevention of fraud in the management of village funds needs to be done because village funds channeled by the government have a very noble goal of building Indonesia from the periphery (village) so that it is appropriate for the management of village funds to be monitored proactively and transparently. In various cases in the public sector, misappropriation of public funds has often disgraced the news so that an effective system is needed to guard the success of village fund management and avoid fraud. The current steps offered by one of the methods in forensic accounting are whistleblowing systems. A practical, transparent, and responsible 
whistleblowing system will encourage and increase employee participation to report suspected fraud. This system is a breakthrough in the supervision and effectiveness of village fund management for accountable and transparent accountability purposes. Distribution of village funds in Bali can be believed to be very well distributed because it has a very strong culture in each village. However, it is certain that in each village the village funds have their interests and needs related to infrastructure development, community economic development, education and so on. Whatever the interests and needs of villages receiving village funds, the main principles that must be held in managing village funds are honest, transparent, accountable, and accountable. The point is the management of village funds according to existing regulations, intended for all needs needed to improve the welfare of rural communities to support government programs to develop Indonesia from the village. This research aims to analyse whether whistleblowing influences fraud prevention in managing village funds, and whether the implementation of the Tri Hita Karana culture influences fraud prevention in managing village funds

\section{Method}

The population in this study were all village heads who lead service villages in the Bali Province. Purposive random sampling method was employed hence the village heads who had a tenure of more than one year and were expected to have adequate knowledge, understanding of sufficient working environment conditions, and have comprehensive perceptions and considerations of fraud, whistleblowing, and also Tri Hita Karana culture, were taken as samples. The number of village heads who met the sampling criteria was 716 village heads. Of these, the sample respondents were 88 people. The number of samples is still accepted in the sample range for correlational research, which is $>30$ or $<500$ [13].

The data used in this study is primary data obtained directly from the source. Data used in the form of opinions from research subjects collected by using the survey method, namely through a questionnaire. Data collection was done using personally administered questionnaires (personal questionnaires) which means that researchers can relate directly to respondents and provide explanations as needed about the questionnaire and can be directly collected after being answered by the respondents [14]. In the technique of collecting data with this personal method, the distributed questionnaire achieved 100 percent response rate.

\section{Questionnaire Design}

The scale used for the measurement is the Likert scale, which is expressed with a range of numbers 1 to 5 . Fraud is a deliberate fraud that causes loss without being realized by the aggrieved party and provides benefits to the perpetrators of fraud [15]. There are two other important concepts related to fraud prevention besides effective internal control, namely instilling awareness about fraud (fraud awareness) and efforts to assess the risk of fraud (fraud risk assessment) [5]. Thus, in this study to measure fraud prevention variables used the concept of learning to report to the nation, namely anti-fraud controls (AFC) which of course was modified and adapted to the research objectives. Fraud prevention consists of 16 questions tailored to the components of the AFC.

The instrument for implementing the tri hita Karana culture follows the questionnaire model in Saputra (2012) research [11]. Questionnaire questions were designed positively 3 (three) indicators submitted as an organizational culture are an integrity, work ethic, and environmental sustainability. In the elaboration, each indicator is made into the form of operational guidance in the form of a description/description, namely: (1) The intended integrity is to be cautious, dedicated, and uphold honesty; (2) Work ethic is creativity, hard work without knowing despair, respecting time, harmonious cooperation, Satya wacana, ethical efficiency, and full of initiative; (3) environmental sustainability is to build, maintain, and secure or protect the environment.

\section{Results and Discussion}

The profile of respondents in this study was grouped by sex, age, and tenure. Characteristics of respondents based on gender indicate that the percentage of village heads male sex is $97.5 \%$ and women are $2.5 \%$. Based on age, it was found that at 30-39 years old there were $27.5 \%$, respondents were at the age of $40-49$ years as much as $42.5 \%$, at the age of $50-59$ years as many as $20 \%$ and the 
age above 60 years at $10 \%$. Most of the tenure of respondents under 6 years is $57.5 \%$, and above 6 years is $42.5 \%$.

The results of testing the instrument validity indicate that the instrument used in this study is valid, which is indicated by the value of Corrected item-total Correlation, all of which are greater than R Table (0.2096). The R-table in question is obtained from the calculation of DF $=\mathrm{N}-2$ and probability of 0.05 . The reliability test results show the Cronbach's Alpha value Based on Standardized Items for all the variables used in this study is greater than R-Table or greater than 0.70 so that overall is considered reliable. This is because all research instruments were tested beforehand, and also, some of the instruments used came from previous research. The normality test with Kolmogorov-Smirnov test shows that the significance of 0.758 is more significant than 0.05 , so it can be concluded that the data tested are normally distributed. The multicollinearity test has seen from the tolerance values of variables X1, X2, and X3 which are $0.967,0.980$ and 0.985 is greater than 0.10 , and the VIF value is 1.034 for X1, 1.020 for X2, and 1.015 for X3 which means less than 10, so it is proven not the presence of multicollinearity. While the results of heteroscedasticity test with glejser test show the significant value of all variables more than 0.05 , which indicates there is no heteroscedasticity in the regression model.

Table 1. Multiple Linear Regression Test Results

\begin{tabular}{|c|c|c|c|c|c|}
\hline \multicolumn{6}{|c|}{ Coefficients } \\
\hline Model & Unstandardize & cients & $\begin{array}{l}\text { Standardized } \\
\text { Coefficients }\end{array}$ & $\mathrm{t}$ & Sig \\
\hline 1 (Constant) & 14.161 & 5.412 & & 2.616 & .011 \\
\hline WHS & -.016 & .080 & -.022 & -.200 & .842 \\
\hline THK & -.019 & .073 & -.029 & -.266 & .791 \\
\hline
\end{tabular}

The results proves that the whistleblowing variable has not yet reached its existence in village financial management. Whistleblowing is not yet needed in village financial management because village government has an organizational basis with non-complex personnel such as regional government and central government so that in the village government has high confidence in the apparatus because all come from one village. More than that, in the life of the village in Bali, there is tremendous confidence in their fellow human beings in the form of tolerance, kinship and godliness manifested in the teachings of tat wam asi which means "I am you, so you are me". This is what makes Hindus in Bali in managing the village convinced that we will get a fair reward for what we do to others. In everyday life, this teaching is known as karma, therefore there is no need to report each other. The Hindus prefer to conduct investigations together if fraud occurs and uphold the principles of honesty, transparency, and accountability in managing village funds. Reflecting on these teachings, the whistleblowing method is not yet needed in managing village funds in Bali, and they prioritize individual trust and the protection of influential traditional village organizations (spirituality). So in this study, whistleblowing variables do not have a significant effect on fraud prevention. Although it is difficult to translate these teachings compared to whistleblowing, Balinese who manage village funds entrust the traditional study and rules of each village, the legal protection of the indigenous/adat village (awig-awig) is one of the triggers of confidence. High level of confidence in managing village funds honestly, transparently, and accountably. The results of this study are different from previous research [8], which states that whistleblowing has a strong influence on fraud that occurs in government organizations, which in this case the government auditor as the research respondent.

Further, the results indicate that Tri Hita Karana as local culture has a significant effect on fraud prevention in managing village funds. This is because the Tri Hita Karana teaching is very quickly adopted in the culture of village government organizations. The teachings of tri hita Karana have even taken root in the life of the Balinese Hindu community. This local culture is believed to be a benchmark for human behavior in organizing and in decision making. All organizations in Bali must be based on Tri Hita Karana because their teachings are trusted and recognized by the wider community. Synergizing with fellow human beings, respecting and caring for each other with the 
universe, and believing in God Almighty, these are its teachings that make people in this world live happily and respectfully, and protect each other. Tri Hita Karana teachings are considered capable of preventing fraud in managing village funds. From the results of this study it can be shown that Tri Hita Karana teachings is highly believed to be adopted into a work culture in village governance so as to create village fund management to avoid fraud. With the adoption of the Tri Hita Karana teachings as organizational culture, village officials in Bali have full responsibility for God, fellow village communities, and their environment [16]. If fraud were to be conducted, besides the legal process, the traditional village sanctions process would be more severe.

\section{Conclusion}

Research that uses the Tri Hita Karana variable has been conducted before $[3,11,12,16]$, but not in the context of village governance. This is the novelty of the research. Based on the research results, whistleblowing does not show a significant effect on fraud prevention. This is because in village government and management of village funds place more trust Tri Hita Karana as prevention of fraud. The Tri Hita Karana teachings would encourage people to trust each other, respect each other and do not accuse each other, which result in the effectiveness of both national law and indigenous law in overcoming fraudulent perpetrators. The result also indicates tha the implementation of Tri Hita Karana culture has a significant influence on the prevention of fraud in management and the village. This is natural because the Balinese Hindu community strongly believes in the Tri Hita Karana teachings both in daily life and in an organization [16]. The teachings of tri hita Karana can protect organizations from all forms of fraud because this teaching has been embedded in each of Balinese society.

This research is expected to contribute to interested parties such as the village government in managing village funds, formulating budgets or using village funds according to central government regulations in accordance with the principles of honesty, transparency, and accountability. For the general public to know that all flows of funds from the government are indeed very vulnerable to fraud, so it needs to be protected by various systems and local cultures that exist in each region. The community must also know that there are many types of fraud that can be done by some aspects of managing village funds.

\section{References}

[1] Dewi R, Apandi RNN. Gejala Fraud dan Peran Auditor Internal dalam Pendeteksian Fraud di Lingkungan Perguruan Tinggi. Simp. Nas. Akunt. XV, Banjarmasin: 2012.

[2] Saputra KAK. Prinsip Dualitas dan Akuntansi Sumber Daya Manusia dalam Keberhasilan Pengelolaan Dana Desa. J Anal Akunt Dan Perpajak 2019;2.

[3] Saputra KAK, Sujana E, Tama G. Perspektif Budaya Lokal Tri Hita Karana dalam Pencegahan Kecurangan pada Pengelolaan Dana Desa. J Akunt Publik 2018;1.

[4] Putri CM. Pengujian Keefektifan Jalur Pelaporan pada Structural Model dan Reward Model dalam Mendorong Whistleblowing. Simp. Nas. Akunt. XV, Banjarmasin: 2012.

[5] Tuanakotta TM. Akuntansi Forensik dan Audit Investigatif. Jakarta: Penerbit Salemba Empat; 2012.

[6] Miceli MP, Near JP, Schwenk CR. Who Blows The Whistle and Why? Ind Labor Relat Rev 1991;45:113-30.

[7] Susmanschi G. Internal Audit and Whistle-Blowing. Econ Manag Financ Mark 2012;7:41521.

[8] Rustiarini NW, Sunarsih NM. Fraud dan Whistleblowing: Pengungkapan Kecurangan Akuntansi oleh Auditor Pemerintah. Simp. Nas. Akunt. XVIII, Medan: 2015.

[9] Riana IG. Dampak Penerapan Kultur Lokal Tri Hita Karana terhadap Orientasi Kewirausahaan dan Orientasi Pasar serta Konsekuensinya pada Kinerja Usaha (Studi pada IKM Kerajinan Perak di Bali). Universitas Brawijaya, 2010.

[10] Tenaya GAI. Analisis Falsafah dan Konsep Akuntansi dalam Perspektif Filsafat Kultur Bali Tri Hita Karana dan Kesadaran Internal Lembaga terhadap Hukum Perusahaan. Universitas Brawijaya, 2007.

[11] Saputra KAK. Pengaruh Locus of Control terhadap Kinerja Internal Auditor dengan Kultur 
Lokal Tri Hita Karana sebagai Variabel Pemoderasi. J Akunt Multiparadigma 2012;3:86100 .

[12] Gunawan K. Pengaruh Budaya Organisasi, Kepuasan Kerja dan Motivasi Kerja terhadap Gaya Kepemimpinan dan Kinerja Organisasi (Studi pada Lembaga Perkreditan Desa (LPD) di Bali). Universitas Brawijaya, 2009.

[13] Sekaran U, Bougie R. Research Methods for Business: A Skill Building Approach. New York: Chichester Wiley; 2010.

[14] Indriantoro N, Supomo B. Metode Penelitian Bisnis (Untuk Akuntansi dan Manajemen). Yogyakarta: BPFE; 2009.

[15] Ramadhaniyati Y, Hayati N. Pengaruh Profesionalisme, Motivasi, Integritas, dan Independensi Satuan Pengawasan Internal dalam Mencegah Kecurangan (Fraud) di Lingkungan Perguruan Tinggi Negeri. JAFFA 2014;2:101-14.

[16] Atmadja A., Saputra A. Pencegahan Fraud dalam Pengelolaan Keuangan Desa. J Ilm Akunt Dan Bisnis 2017;1:7-16. 